Short Communication

\title{
Improving the Anti-Corrosion Ability of Anodization Film of AZ31B Magnesium Alloy by Addition of $\mathrm{NH}_{4} \mathrm{VO}_{3}$ in the Electrolyte
}

\author{
Yujun Si ${ }^{*}$, Zhongping Xiong, Xingwen Zheng, Minjiao Li, Qinhuan Yang \\ Material Corrosion and Protection Key Laboratory of Sichuan Province, College of Chemistry and \\ Pharmaceutical Engineering, Sichuan University of Science and Engineering, Zigong 643000, P.R. \\ China \\ *E-mail: syj08448@163.com
}

doi: $10.20964 / 110296$

Received: 18 December 2015 / Accepted: 8 March 2016 / Published: 1 April 2016

\begin{abstract}
AZ31B magnesium alloy was anodized in an alkaline electrolyte containing sodium borate, sodium silicate and sodium citrate. Ammonium metavanadate $\left(\mathrm{NH}_{4} \mathrm{VO}_{3}\right)$ was used as an additive to improve the anti-corrosion ability of anodization film. The anodization film was characterized by X-ray diffraction and scanning electron microscopy. The anti-corrosion ability of the film was evaluated by electrochemical impedance spectrum. The results show that $\mathrm{VO}_{3}{ }^{-}$ions react with $\mathrm{Mg}^{2+}$ to form yellow magnesium vandate. Magnesium oxide in anodization film is restrained by $\mathrm{VO}_{3}{ }^{-}$. The pores on the film decreases and the cracks can be filled by the addition of $\mathrm{NH}_{4} \mathrm{VO}_{3}$. The film also becomes smoother and compacter which increase the resistance of film and charge transfer resistance of the corrosion process of the AZ31B magnesium alloy. The anti-corrosion ability of the anodization film is obviously enhanced.
\end{abstract}

Keywords: Magnesium alloy; anodization film; anti-corrosion; ammonium metavanadate

\section{$\underline{\text { FULL TEXT }}$}

(C) 2016 The Authors. Published by ESG (www.electrochemsci.org). This article is an open access article distributed under the terms and conditions of the Creative Commons Attribution license (http://creativecommons.org/licenses/by/4.0/). 